\title{
Studies on the control of gluconeogenesis in sheep: effect of glucose infusion
}

\author{
BY G. J. JUDSON* AND R. A. LENG \\ Department of Biochemistry and Nutrition, School of Rural Science, \\ University of New England, Armidale, New South Wales, 235I, Australia
}

(Received 17 December 1971 - Accepted 29 fune 1972)

\begin{abstract}
I. Effect of glucose infusions on the rate of gluconeogenesis, as indicated by changes in the irreversible loss of plasma glucose, synthesis of glucose from ruminal propionate or fixation of blood bicarbonate into glucose, has been examined in sheep.

2. Sheep, feeding at hourly intervals, received intravenous infusions of $\left[\mathrm{U}^{14} \mathrm{C}\right] \mathrm{glucose}$, $\mathrm{NaH}^{14} \mathrm{CO}_{3}$, or $\left[6^{3} \mathrm{H}\right]$ glucose, infused simultaneously with an intraruminal infusion of $\left[2-{ }^{14} \mathrm{C}\right]$ propionate. Glucose $(4-144 \mathrm{mg} / \mathrm{min})$ was infused intravenously at a single rate or at two different successive rates of equal duration. The glucose infusions were over a $6 \mathrm{~h}$ period and followed estimates of pre-infusion kinetic measurements.

3. The infusion of glucose suppressed endogenous glucose production in direct proportion to that infused for sheep given diets of lucerne or wheat. The maximum rate of suppression recorded was equivalent to about $50-60 \%$ of the endogenous production rate of glucose.

4. Transfer rates of carbon-I4 from blood bicarbonate or ruminal propionate to plasma glucose were reduced during glucose loadings. The results indicate that administration of glucose was more effective in suppressing the synthesis of glucose from substrates other than ruminal propionate.

5. The percentage of glucose carbon derived from blood bicarbonate was lower in sheep given wheat than in sheep given lucerne. It was suggested that this difference may have been due to absorption of glucose from the alimentary canal of sheep on the former ration. Approximatcly $8 \%$ of the wheat starch may have escaped fermentation and been absorbed as glucose in these animals.
\end{abstract}

Little is known about the control of gluconeogenesis in ruminants although recent evidence has indicated that diet may be an important factor affecting its rate in sheep (Ford, 1965; Judson \& Leng, I968; Steel \& Leng, 1968). Previous findings from this laboratory, with sheep on diets of varying maize content, have shown that glucose synthesized from ruminal propionate decreased as the maize content of the diet increased even though the propionate produced in the rumen was similar (Judson, Anderson, Luick \& Leng, 1968). It was suggested that glucose absorption from the gastro-intestinal tract may have increased as the grain content of the diet was increased and that this suppressed gluconeogenesis from propionate. Glucose infusions have previously been shown to abolish or markedly inhibit gluconeogenesis in sheep (Annison \& White, 196r; Annison, Lindsay \& White, 1963; West \& Passey, 1967) and cattle (Bartley \& Black, I966). However, these animals were usually without food for approximately $24 \mathrm{~h}$ and the glucose infused was equivalent to or greater than the endogenous production rate of glucose.

The object of the present study was to measure the effect of glucose infusions on the rate of gluconeogenesis in the fed sheep, as indicated by changes in (I) the

* Present address: Division of Animal Science, Institute of Medical and Veterinary Science, Frome Road, Adelaide, South Australia, 5000, Australia. 
irreversible loss of plasma glucose, (2) the synthesis of glucose from ruminal propionate and (3) the fixation of blood bicarbonate carbon into glucose.

\section{EXPERIMENTAL}

Animals and diets. Twelve Merino ewes or wethers, aged 3-5 years, were used and were housed in single pens. They were given either $800 \mathrm{~g}$ lucerne chaff (ration A) or $400 \mathrm{~g}$ wheat with $5 \circ \mathrm{g}$ lucerne chaff and $5 \mathrm{~g}$ limestone (ration B) daily. The respective digestible energy and crude protein contents were approximately $7.95 \mathrm{MJ}$ and $97 \mathrm{~g}$ for ration $\mathrm{A}$ and, $5.8 \mathrm{MJ}$ and $45 \mathrm{~g}$ for ration B. Digestibility of the diets was determined over 8-1o d. The gross energy of food and faeces was measured in an adiabatic bomb calorimeter (Gallenkamp \& Co. Ltd) and crude protein (nitrogen $\times 6.25$ ) was determined as described by Clare \& Stevenson (1964). Three of the sheep given ration $A$ were fitted with rumen cannulas.

Experimental procedures. At least $5 \mathrm{~d}$ before administration of radioactive isotopes, the animals were transferred to metabolism cages and were given their daily ration in twenty-four equal quantities at hourly intervals from an automatic feeder. On the day before the infusion of isotopes, catheters were inserted into both jugular veins, one to be used for administering isotopes and the other for obtaining blood samples.

[U-1 ${ }^{14}$ ] $]$ Glucose $(0.06-0.08 \mu \mathrm{Ci} / \mathrm{min}),\left[6-{ }^{3} \mathrm{H}\right]$ glucose $\left(0 .{ }_{1} \mathrm{I}-0.47 \mu \mathrm{Ci} / \mathrm{min}\right)$ or $\mathrm{NaH}-$ ${ }^{14} \mathrm{CO}_{3}\left(0^{\circ} 4{ }^{0-1} \cdot 93 \mu \mathrm{Ci} / \mathrm{min}\right)$ was infused intravenously as described by Annison \& White (1961) on the 5 th or 7 th day of the interval-feeding regimen. $\left[2-{ }^{14} \mathrm{C}\right]$ Propionate ( $0 . \mathrm{I} \mathrm{I}-\mathrm{O} . \mathrm{I} 3 \mu \mathrm{Ci} / \mathrm{min}$ ) was infused intraruminally, simultaneously with intravenous infusions of $\left[6^{3} \mathrm{H}\right]$ glucose, and ruminal contents were sampled as described by Leng \& Leonard (1965).

Isotope infusions were commenced between 05.00 hours and 07.00 hours and usually consisted of two or three successive periods, each of between 3 and $8 \mathrm{~h}$ duration. The first period was used to obtain control values for the concentration and specific radioactivity (SR) of metabolites isolated from blood (and ruminal fluid). Between 4 and $140 \mathrm{mg}$ glucose/min were infused intravenously during the second and third periods. The amount of glucose was varied by infusing from solutions of glucose $(20-400 \mathrm{~g} / \mathrm{l})$ at rates between 0.18 and $0.37 \mathrm{ml} / \mathrm{min}$. Separate catheter leads were used to convey the infused glucose and isotope to the animal but were joined by a Y-piece to the catheter in the vein. Samples of blood and ruminal fluid were taken at $20-30$ min intervals, $2-3 \mathrm{~h}$ immediately before and during a glucose infusion.

Chemical analyses and determination of radioactivity. Glucose concentration was determined by the method of Huggett \& Nixon (1957) and plasma glucose was isolated and assayed for radioactivity as the penta-acetate derivative (Jones, 1965). Radioactivity was measured with a TriCarb liquid scintillation spectrometer (model 3320, Packard Instrument Co. Ltd) and the external standard was calibrated to correct for quenching (Felts \& Mayes, 1967). For convenience these settings were also used for single counting of tritium and carbon-I4. Plasma lactate was estimated by the lactate dehydrogenase method of Barker \& Britton (1957) and plasma urea was determined with an AutoAnalyzer by Technicon method number N-i6 (Technicon 
Instrument Corporation, Cauncey, New York, USA). Blood bicarbonate was isolated and assayed for radioactivity as barium carbonate by the method of Leng \& Leonard (1965), except that the $0.5 \mathrm{M}_{-} \mathrm{H}_{2} \mathrm{SO}_{4}$ injected into blood contained $\mathrm{CuSO}_{4}$ ( $\mathrm{I} \circ \mathrm{g} / \mathrm{l}$ ) to prevent bacterial action. These authors also give the methods used for estimation of total volatile fatty acids (VFA) in ruminal fluid and the isolation of propionate and its assay for radioactivity.

Radioactive compounds were obtained from The Radiochemical Centre, Amersham, Bucks., and were made to volume with physiological saline containing $0.3-0.5 \mathrm{mmol} / 1$ of the non-labelled substrate as carrier. Known volumes of these isotope solutions were either infused intravenously at approximately $0.2 \mathrm{ml} / \mathrm{min}$ or intraruminally at approximately $0.4 \mathrm{ml} / \mathrm{min}$. Samples of these solutions were prepared for assay of radioactivity as described for blood or ruminal fluid substrates.

Calculations. The irreversible loss of a metabolite is calculated by comparing the 'plateau' SR of the metabolite with the rate of infusion of the labelled metabolite (see Gurpide, Mann \& Lieberman, 1963; Tait, 1963). In these studies, the plateau SR of a metabolite was assumed to be attained when the SR of the metabolite was approximately constant over a period of time and where there was no significant slope $(P>0.05)$, as tested by least-squares regression analysis. It is possible that in some studies a slight slope may not have been detected which would have resulted in inaccurate estimates of the irreversible loss of the metabolite or its contribution to another substrate. However, the magnitude of this error was probably small since, even when only a few results were available, any trend in slope was not apparent. The coefficient of variation about the mean value of the plateau SR for four or more observations taken at $20-30 \mathrm{~min}$ intervals was usually between 3 and $7 \%$.

The rate of synthesis of glucose from ruminal propionate was determined as described by Leng, Steel \& Luick (1967), except that $\left[6{ }^{3} \mathrm{H}\right]$ glucose was infused simultaneously with intraruminal infusions of $\left[2{ }^{14} \mathrm{C}\right]$ propionate. Judson \& Leng (1970) have shown that estimates of the irreversible loss of glucose in sheep with constant infusions of $\left[\mathrm{U}^{-14} \mathrm{C}\right] \mathrm{glucose}$ and $\left[6-{ }^{3} \mathrm{H}\right] \mathrm{glucose}$ were similar.

\section{RESULTS}

Irreversible loss of plasma glucose. Sheep received constant infusions of $\left[\mathrm{U}-{ }^{14} \mathrm{C}\right]-$ or $\left[6^{-3} \mathrm{H}\right]$-glucose for approximately $12 \mathrm{~h}$. The SR of plasma glucose plateaued from $3^{-4} \mathrm{~h}$ after the start of this infusion. In the second $6 \mathrm{~h}$ of the isotope infusion, between 4 and $140 \mathrm{mg}$ glucose/min were infused either at a single rate or at two different successive rates for equal periods (see Figs $\mathrm{I}$ and 4 ). The glucose infusion usually resulted in a gradual decrease in the SR of plasma glucose for $\mathrm{I}-3 \mathrm{~h}$ before the glucose SR fell to a new plateau. This plateau was maintained for intervals up to $5 \mathrm{~h}$ during the infusion of glucose (see Fig. I).

The increase in the irreversible loss of plasma glucose in response to a glucose infusion was less than the quantity of glucose infused, indicating that the irreversible loss of endogenous glucose was suppressed (Fig. 2). The percentage of this endogenous glucose suppressed $\left(Y_{s}\right)$ was linearly related $(P<0.0 \mathrm{I})$ with the glucose 


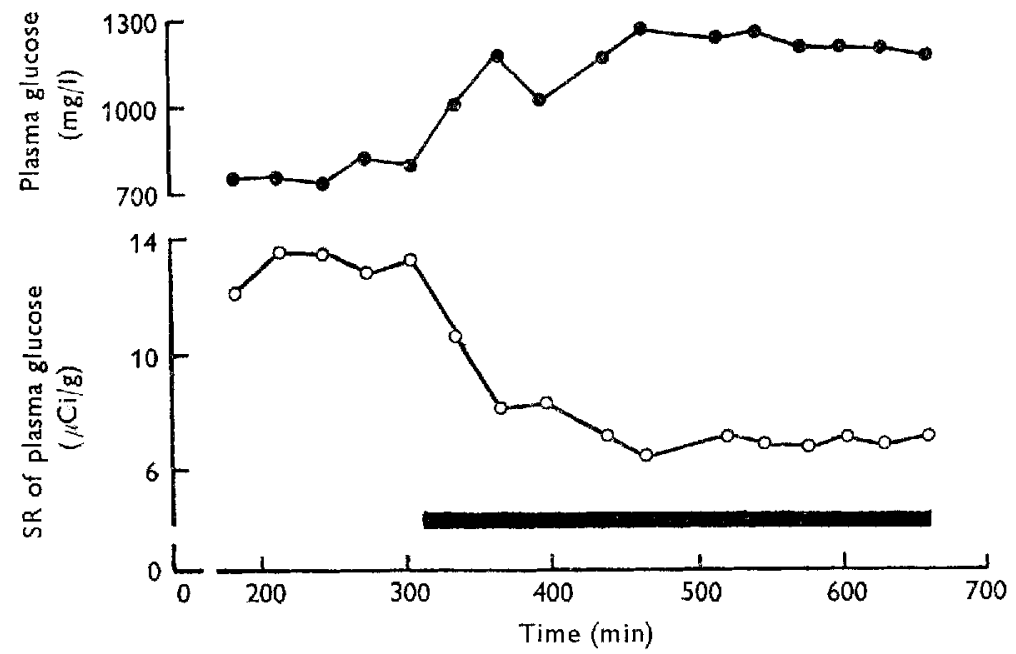

Fig. I. Effect of an intravenous infusion of glucose on the specific radioactivity (SR) and concentration of plasma glucose in sheep no. 175 , given $800 \mathrm{~g}$ lucerne daily and a constant infusion of $\left[\mathrm{U}^{14} \mathrm{C}\right] \mathrm{glucose}$. $\mathrm{O}, \mathrm{SR}$ of glucose, standardized to an infusion rate of $\mathrm{r} \mu \mathrm{Ci} / \mathrm{min}$; - concentration of glucose. The infusion rate of glucose from the 3 roth to the 66 oth minute (horizontal bar) of the isotope infusion was $99 \cdot 3 \mathrm{mg} / \mathrm{min}$.

administered $\left(X_{G}, \mathrm{mg} / \mathrm{min}\right.$ ) in sheep given lucerne (ration A) but this relationship was not significant $(P>0.05)$ when wheat (ration B) was given (Fig. $3 a)$. However, these relationships were not significantly different $(P<0.05)$ in slope or intercept and the regression equation for the pooled results was:

$$
\left.Y_{3}=\mathrm{I} 4.2+0.287 X_{G} \text { [SE of slope }= \pm 0.06 \mathrm{r} 3, \mathrm{RSD}= \pm \mathrm{II} \cdot \mathrm{I}, P<0.00 \mathrm{r}\right] \text {. }
$$

The suppression of the irreversible loss of endogenous glucose $\left(Y_{Q}, \mathrm{mg} / \mathrm{min}\right)$ increased linearly with the rate of infusion of glucose $\left(X_{G}, \mathrm{mg} / \mathrm{min}\right)$ in sheep given lucerne $(P<0.00 \mathrm{I})$ or wheat $(P<0.05)$ (Fig. $3 b)$. These relationships were similar in slope and intercept $(P<0.05)$ and the combined regression equation relating these measurements was:

$$
Y_{Q}=6.87+0.192 X_{G}[\mathrm{SE} \text { of slope }= \pm 0.0350, \mathrm{RSD}= \pm 6.32, P<0.001] \text {. }
$$

Plasma glucose concentrations. The response in plasma glucose concentration to a glucose infusion was similar for sheep on lucerne or wheat. In general, the plasma glucose concentrations rose to a maximum value between 100 and $200 \mathrm{~min}$ after the start of the infusion and then were maintained or declined slowly for the rcmainder of the glucose infusion (see Figs $\mathrm{x}$ and 4 ). Glucose excreted in urine was negligible, a maximum value of $0.03 \mathrm{mg} / \mathrm{min}$ was measured when sheep 29 received $137 \mathrm{mg}$ glucose/min (see Fig. 2). Where the plasma glucose concentration varied during infusions of glucose, the mcan concentration was calculated from samples corresponding to the plateau SR of plasma glucose.

The relationships between the irreversible loss of plasma glucose $\left(Y_{P}, \mathrm{mg} / \mathrm{min}\right)$ and plasma glucose concentration $\left(X_{C}, \mathrm{mg} / 100 \mathrm{ml}\right)$, the increase in plasma glucose concentration $\left(Y_{I}, \mathrm{mg} / \mathrm{I} 00 \mathrm{ml}\right)$ and the rate of infusion of glucose $\left(X_{G}, \mathrm{mg} / \mathrm{min}\right)$, 

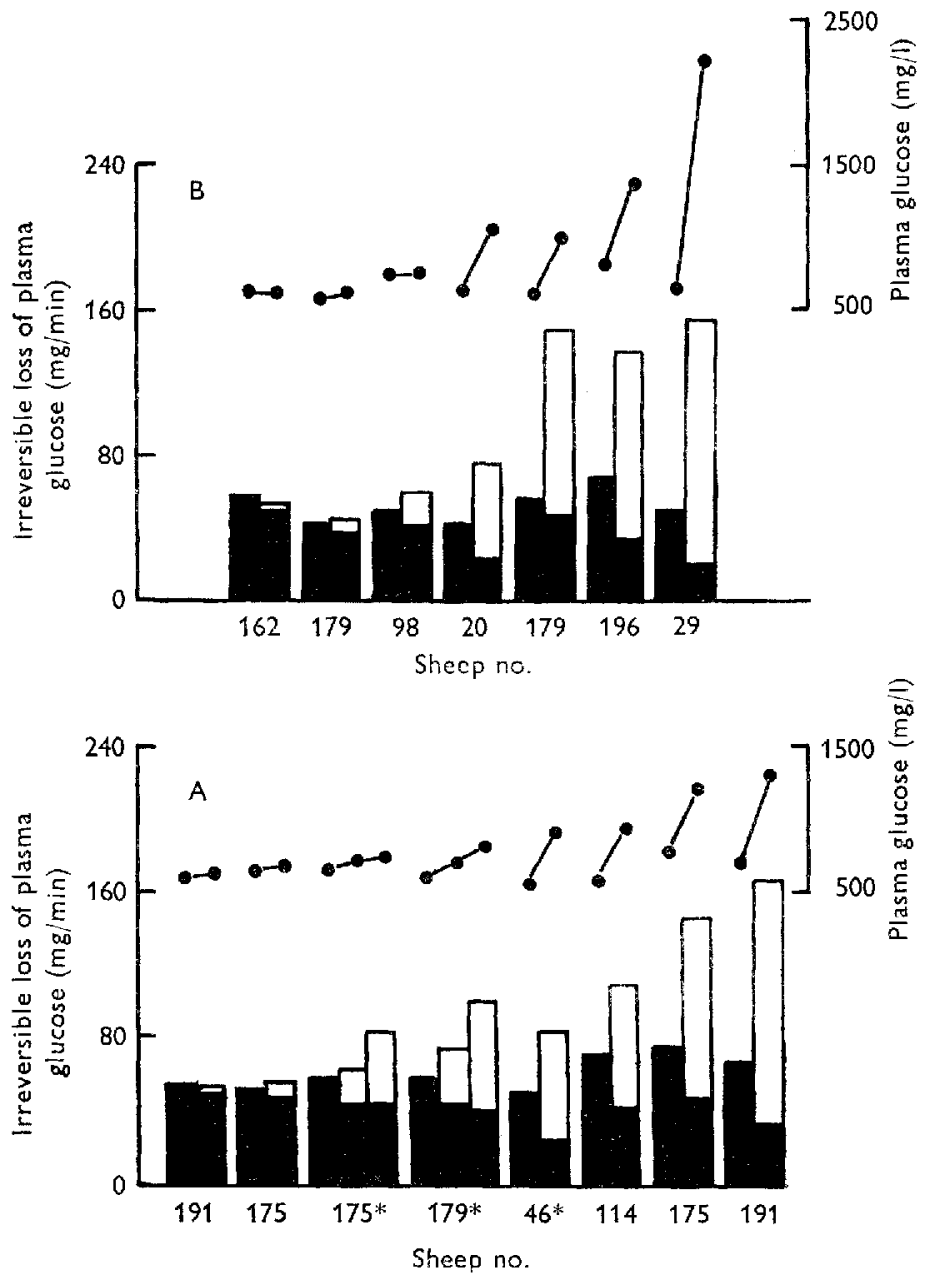

Fig. 2. Effect of intravenous infusion of glucose on the irreversible loss of plasma glucose in sheep given wheat (B) or lucerne (A). Each set of two or three vertical columns represents one experiment with a sheep whose number is listed beneath the columns. Exogenous glucose was administered in the second (and third) period and the rate of infusion $(\mathrm{mg} / \mathrm{min}$ ) is represented by the unshaded column. The irreversible loss of plasma glucose is represented by the height of each column and was measured by using a constant infusion of [U- $\left.{ }^{14} \mathrm{C}\right] g l u c o s e$ or $\left[6-{ }^{3} \mathrm{H}\right]$ glucose. Sheep whose number is marked with an asterisk received the $\left[6-{ }^{3} \mathrm{H}\right] \mathrm{glucose}$. The mean plasma glucose concentration ( ) for each period is shown above the appropriate column.

and the decrease in the irreversible loss of endogenous glucose $\left(Y_{D}, \mathrm{mg} / \mathrm{min}\right)$ and the increase in plasma glucose concentration $\left(X_{I}, \mathrm{mg} / \mathrm{I} 00 \mathrm{ml}\right)$ for sheep given either lucerne or wheat and intravenous infusions of glucose were:

$$
\begin{aligned}
& Y_{P A}=-43 \cdot 2+\mathrm{I} \cdot 610 X_{C A}(n=\mathrm{ro})[\mathrm{sE}= \pm 0.157, \mathrm{RSD}= \pm 10 \cdot 8], \\
& Y_{P^{3} B}=22.6+0.687 X_{C B}(n=7) \quad[\mathrm{SE}= \pm 0.239, \mathrm{RSD}= \pm 33.0], \\
& Y_{I A}=-3.8 \mathrm{I}+0.445 X_{G A}(n=19)[\mathrm{sE}= \pm 0.046, \mathrm{RSD}= \pm 7.5 \mathrm{I}] \text {, } \\
& Y_{I B}=-13.5+0.89 \mathrm{I} X_{G B}(n=\mathrm{I} 0)[\mathrm{SE}= \pm 0.229, \mathrm{RSD}= \pm 37 \cdot \mathrm{I}], \\
& Y_{D A}=7 \cdot 52+0.491 X_{I A}(n=10)[\mathrm{sE}= \pm 0.060, \mathrm{RSD}= \pm 3.5 \mathrm{I}] \text {, }
\end{aligned}
$$



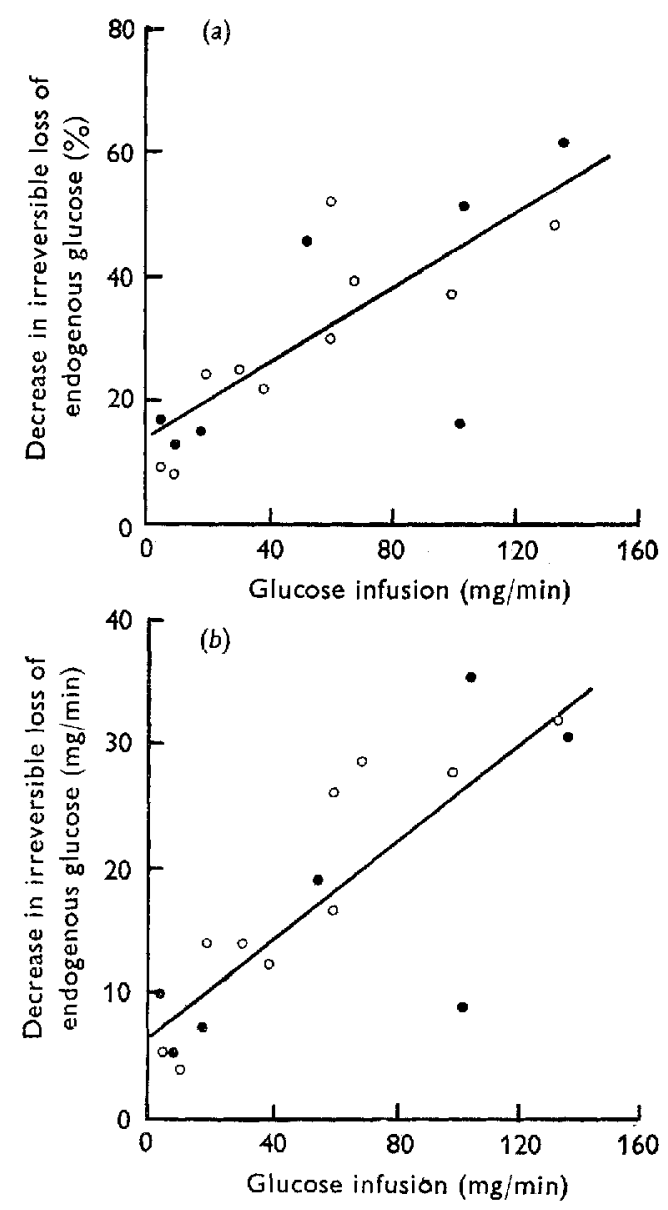

Fig. 3. Relationships between the percentage of the irreversible loss of endogenous glucose suppressed $(a)$ or rate of suppression of the irreversible loss of endogenous glucose $(b)$ and rate of infusion of glucose into sheep given lucerne $(O)$ or wheat $(0)$. Equations for the lines in $3(a)$ and $3(b)$ are no. (I) and no. (2) on p. 162 .

where $n$ is the number of experiments, and subscripts $A$ and $B$ refer to results from animals receiving lucerne and wheat rations respectively.

Equations 3, 5 and 7 were significant at $P<0.00$ r whereas equations 4 and 6 were significant at $P<0.05$ and $P<0.0$ I respectively. The relationship between the decrease in the irreversible loss of endogenous glucose and the increase in plasma glucose concentration for sheep given wheat, was not significant $(P>0.05)$. This relationship also differed significantly $(P<0.05)$ in slope but not intercept to the equation relating these measurements for sheep given lucerne (equation (7)). Equations (3) and (4) were also only significantly different in slope $(P<0.05)$, but equations (5) and (6) were similar in slope and intercept $(P>0.05)$. With these relationships, the difference between diets was largely the result of the apparently exaggerated response in plasma glucose concentration of sheep 29 to a glucose infusion (see Fig. 2 ).

Fixation of blood bicarbonate into plasma glucose. The SR of carbon of blood bicar- 
Table I. Percentage of carbon in plasma glucose derived from bicarbonate of jugular blood and the irreversible loss of bicarbonate in sheep given either lucerne or wheat and intravenous infusions of $\mathrm{NaH}^{14} \mathrm{CO}_{3}$

(Mean values with their standard errors)

\begin{tabular}{|c|c|c|c|c|}
\hline $\begin{array}{l}\text { No. of } \\
\text { expts }\end{array}$ & Ration & $\begin{array}{l}\text { Sheep } \\
\text { wt (kg) }\end{array}$ & $\begin{array}{l}\text { Glucose derived } \\
\text { from } \\
\text { bicarbonate }(\%)\end{array}$ & $\begin{array}{l}\text { Irreversible loss of } \\
\text { blood bicarbonate } \\
\text { (mg C/min) }\end{array}$ \\
\hline 12 & Lucerne & $35 \pm x \cdot 6$ & $14 \pm 0.3$ & $144 \pm 2 \cdot 8$ \\
\hline 5 & Wheat & $32 \pm 2 \cdot 3$ & $10 \pm 0.6$ & $104 \pm 6 \cdot 8$ \\
\hline
\end{tabular}

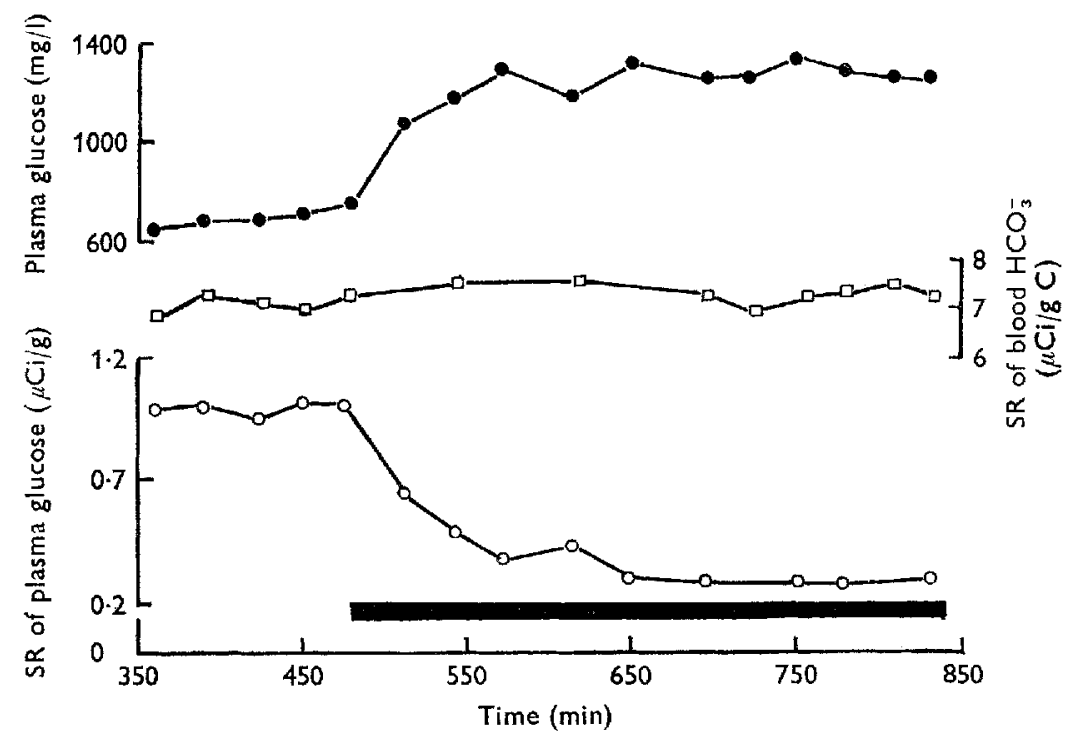

Fig. 4. Effect of an intravenous infusion of glucose on the specific radioactivity (SR) values of plasma glucose and blood bicarbonate and the concentration of plasma glucose in sheep no. I 91 given $800 \mathrm{~g}$ lucerne daily and an intravenous infusion of $\mathrm{NaH}^{14} \mathrm{CO}_{3} . \mathrm{O}, \mathrm{SR}$ of glucose; $\square$, SR of bicarbonate; 9 , concentration of glucose. The SR of plasma glucose and blood bicarbonate were adjusted to an infusion of $\mathrm{I} \mu \mathrm{Ci}$ of $\mathrm{NaH}^{14} \mathrm{CO}_{3} / \mathrm{min}$, and the infusion rate of glucose from the 480 th to the 84 oth minute (horizontal bar) of this isotope infusion was I $33.0 \mathrm{mg} / \mathrm{min}$.

bonate and plasma glucose, in sheep, plateaued from about 3 and $6 \mathrm{~h}$ respectively, after the start of an intravenous infusion of $\mathrm{NaH}^{14} \mathrm{CO}_{3}$ lasting either 9 or $14 \mathrm{~h}$. The irreversible loss of blood bicarbonate and the percentage of glucose carbon derived from blood bicarbonate, calculated by comparing the plateau SR values of carbon, were significantly less $\left(P<0^{\circ} \circ \mathrm{I}\right)$ in sheep given wheat (ration $\left.B\right)$ than in sheep given lucerne (ration A) (Table $\mathrm{r}$ ).

Infusions of between $\mathrm{I} 6$ and $\mathrm{I} 40 \mathrm{mg}$ glucose/min during the final $6 \mathrm{~h}$ of a $\mathrm{I}_{4} \mathrm{~h}$ infusion of $\mathrm{NaH}^{14} \mathrm{CO}_{3}$ did not alter the plateau SR of blood bicarbonate, established before the administration of glucose, but the glucose SR decreased to attain a new plateau some $\mathrm{I}-3 \mathrm{~h}$ later (see Fig. 4). The net rate of synthesis of glucose carbon 
I 66

G. J. Judson and R. A. Leng

1973

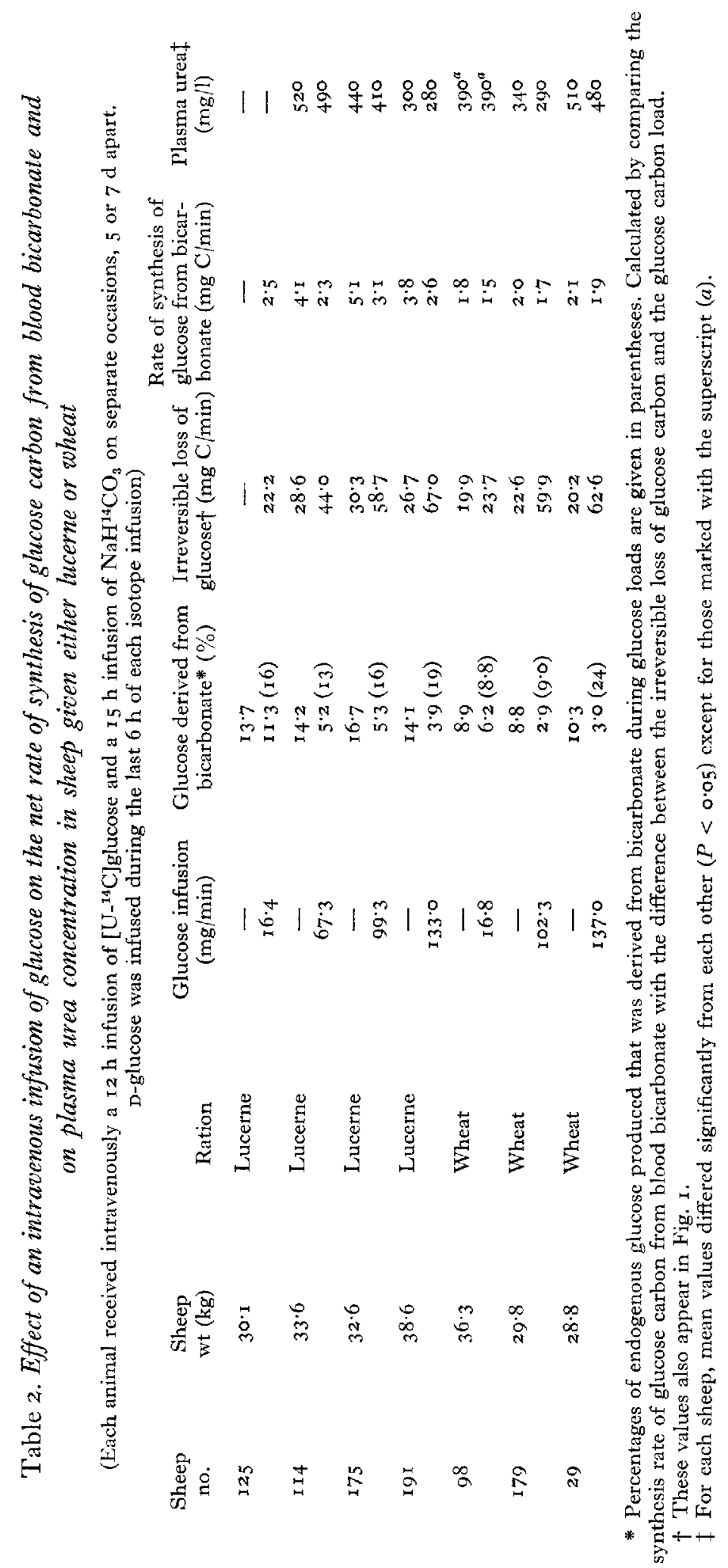




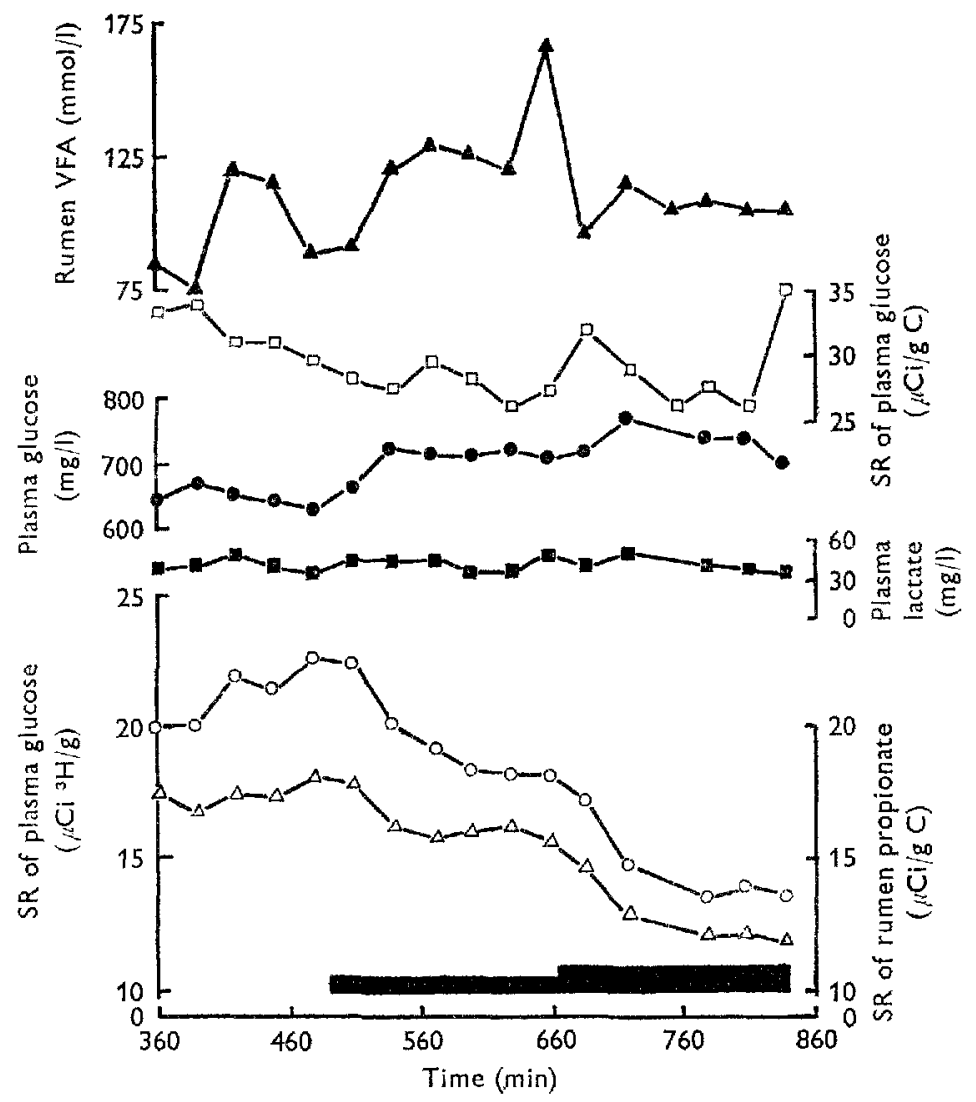

Fig. 5. Effect of successive intravenous infusions of glucose on the plasma concentrations of glucose and lactate and specific radioactivity (SR) values of glucose in sheep no. 175 given $800 \mathrm{~g}$ lucerne daily and an intravenous infusion of $\left[6{ }^{3} \mathrm{H}\right]$ glucose, administered simultaneously with an intraruminal infusion of $\left[2{ }^{14} \mathrm{C}\right]$ propionate. $O, S R$ of glucose carbon; $\triangle, S R$ of glucose

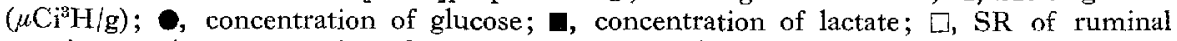
propionate; $\boldsymbol{A}$, concentration of total volatile fatty acids (VFA) in ruminal fluid. The SR of the metabolite was adjusted to an infusion rate of $\mathrm{I} \mu \mathrm{Ci}$ isotope $/ \mathrm{min}$. The infusion rates of glucose between the 48 oth and 66 oth minute and the 66 oth and the 84 oth minute (horizontal bars) of the infusion of isotopes were $19 \cdot 2$ and $38.5 \mathrm{mg} / \mathrm{min}$ respectively.

from blood bicarbonate decreased with the quantity of glucose infused in sheep given either lucerne or wheat, but the percentage of endogenous glucose carbon apparently derived from bicarbonate was not markedly altered, except in sheep given the grcatest quantity of glucose, where the percentage of glucose carbon derived from bicarbonate apparently increased (see Table 2).

Contribution of propionate to glucose synthesis. An intravenous infusion of $\left[6^{3} \mathrm{H}\right]-$ glucose and an intraruminal infusion of $\left[2{ }^{14} \mathrm{C}\right]$ propionate were administered simultaneously for II or I4 h to sheep given lucerne, to measure glucose synthesis from propionate before and during administration of glucosc. The glucose was infused from approximately the 8th $\mathrm{h}$ of the infusion of these isotopes and for about $3 \mathrm{~h}$ at a single rate or for about $6 \mathrm{~h}$ at two different successive rates of equal duration. The results from a typical experiment are given in Fig. 5. 


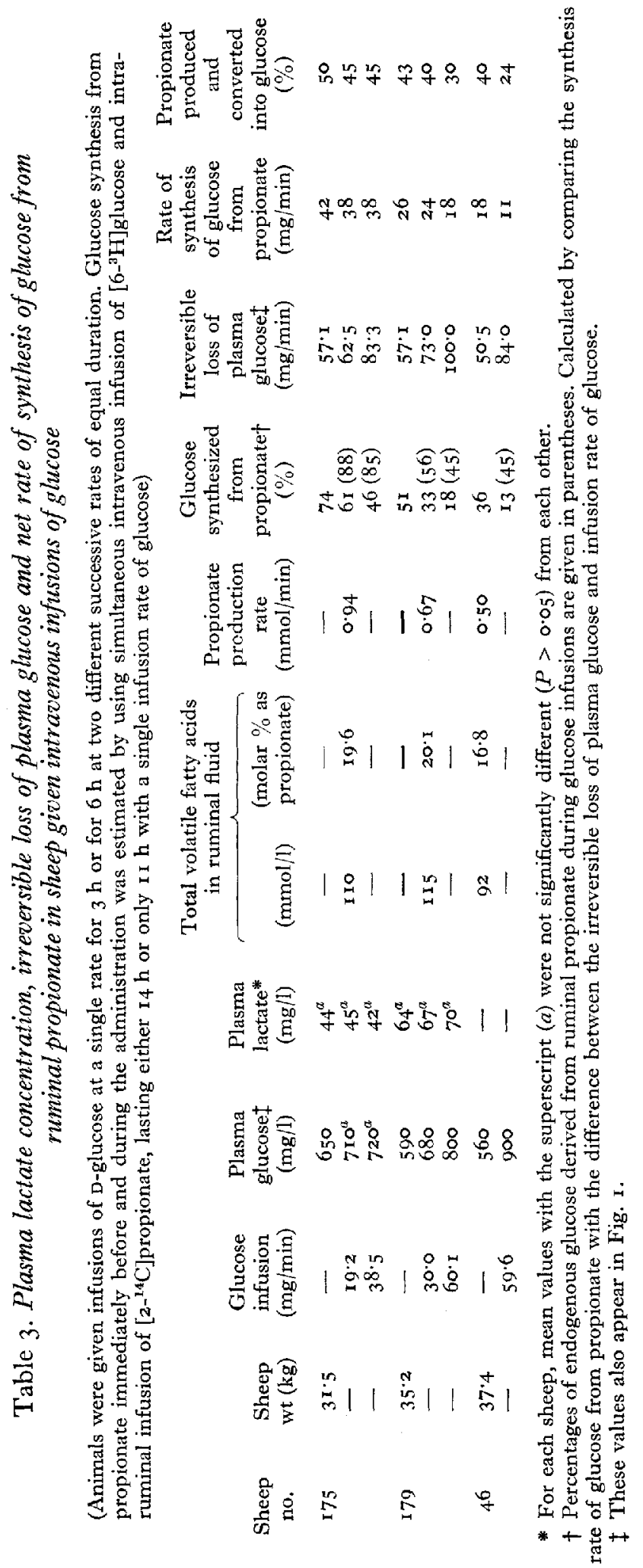


The total concentration of VFA and the SR of propionate in ruminal fluid from $6 \mathrm{~h}$ after the start of a $\left[2-{ }^{14} \mathrm{C}\right]$ propionate infusion (Table 3) showed no significant change $(P>0.05)$ with time, indicating an approximately constant production of gluconeogenic precursors (propionate and microbial protein) during the experimental period. The net rate of glucose synthesis from propionate decreased with the administration of glucose, but the percentage of endogenous glucose apparently derived from ruminal propionate generally increased (Table 3 ) indicating a more effective suppression of glucose synthesis from substrates other than ruminal propionate.

Plasma lactate concentrations were not markedly altered with a glucose infusion (Table 3) but plasma urea concentrations usually decreased to attain an approximately constant level from about the 3 rd hour of the glucose infusion in sheep given either lucerne or wheat (see Table 2).

\section{DISCUSSION}

The present study indicates that the extent of suppression of endogenous glucose production in fed shcep is dependent upon the infusion rate of glucose (Fig. 3). These observations support previous suggestions that a reduction in gluconeogenesis from propionate, found in sheep given diets of different maize and roughage content, may have been related to the quantity of glucose absorbed from the lower digestive tract (Judson et al. I968).

It is possible that the glucose administered to sheep given the wheat diet was in addition to glucose absorbed from the intestinal tract. Variation in the quantities of glucose absorbed, between sheep, may account for the more variable responses in cndogenous glucose production to infused glucose found with sheep on this diet, than with sheep on a lucerne diet. Absorption of glucose in sheep given wheat is also indicated by the lower proportion of glucose carbon derived from bicarbonate carbon-I 4 in these sheep, when compared with sheep given lucerne.

In these studies, the fixation of carbon-I4 from blood bicarbonate into plasma glucose was used as an index of gluconeogenesis. As carbonic anhydrase is usually low or absent in most extravascular tissue (see Roughton, 1935), this permits rapid diffusion of metabolically produced carbon dioxide to extracellular fluid (see Bittar, I964) and its replacement by circulating bicarbonate, 'tagged' with carbon-I4. Two key reactions incorporate bicarbonate carbon into gluconeogenic intermediates. These reactions are ( $\mathrm{I}$ ) the conversion of pyruvate into oxaloacetate by pyruvate carboxylase and the subsequent equilibration of oxaloacetate through malate with a symmetrical molecule of fumarate, and (2) the conversion of propionate into succinate, where propionyl-CoA is converted into methylmalonyl-CoA by propionyl-CoA carboxylase. In the fed ruminant, most of the gluconeogenic substrates (i.e. propionate, lactate and certain amino acids) are converted into glucose by these reactions (Black, Egan, Anand \& Chapman, 1968; Leng, 1970).

Since it is likely that little or no glucose is absorbed from the alimentary tract of sheep on the lucerne diet (see Armstrong \& Beever, 1969; Orskov, 1969) a relationship between the percentage of glucose carbon derived from blood bicarbonate $\left(Y_{P}\right)$ and the percentage contributed by exogenous glucose to the irreversible loss of 
plasma glucose $\left(X_{F}\right)$ in these sheep may be useful in predicting the magnitude of glucose absorption in sheep given other diets. The regression equation relating these measurements for sheep given lucerne (see Table 2) was:

$$
\left.Y_{P}=I_{5} .5-0.153 X_{P} \text { [SE of slope }= \pm 0.0225, \mathrm{RSD}= \pm 0.830, P<0.05\right]
$$

For the three sheep given the wheat diet (see Table 2), where $8 \cdot 8-10 \cdot 3 \%$ of glucose carbon was apparently from bicarbonate, it may be predicted from equation (8) that about $34-44 \%$ of the irreversible loss of plasma glucose was derived from exogenous glucose. This suggests that glucose absorbed from the small intestine was equivalent to about $8 \%$ of the wheat starch ingested (see Kerr, 1950), which is only slightly greater than the estimate of $6 \%$ of MacRae \& Armstrong (1969) for sheep on diets of whole barley, but is less than values of $12-29 \%$ for sheep given crushed maize (Tucker, Mitchell \& Little, I968; Orskov, Fraser \& Kay, ı969; Beever, Coehlo da Silva \& Armstrong, 1970). These differences are probably due to wheat and barley starch being less resistant than maize starch, to ruminal fermentation (Orskov et al. I969; Beever et al. 1970).

In the present study, only a small proportion (usually less than $10 \%$ ) of the glucose administered to sheep was apparently retained in extracellular fluid, as indicated by the change in plasma glucose concentration. Reid (1958) reported that the inclusion of grain ( $900 \mathrm{~g}$ of crushed maize daily) with roughage in a ration accelerated the rate of removal of injected glucose in sheep. Enhanced rates of removal of injected glucose were also apparent in hyperphagic goats given concentrate ad lib. (Baile, Mayer, Mahoney \& McLaughlin, 1969). Glucose was probably absorbed on these high-starch diets and may have increased the animals' 'tolerance' to a glucose infusion. Improved rates of glucose disappearance following repeated glucose infusion have been reported for humans (see Szabo, Maier, Szabo \& Camerini-Davalos, 1969). An explanation for the similarity in the rate of removal of exogenous glucose from plasma of sheep given either lucerne or wheat (compare equations 5 and 6 ) is in the feeding regimen adopted in the present study. The ration was given in equal amounts hourly throughout the day, thus minimizing any adaptation process in sheep given grain once daily as was done by Reid (1958). The decline in the peak concentration of plasma glucose, which occasionally occurred during a $6 \mathrm{~h}$ infusion of glucose to sheep given wheat or lucerne, may indicate some adaptation to glucose intake.

Bergman (1964) suggested that the rate of utilization of glucose in sheep is a function of plasma glucose concentration. This is only indicated in the present study with sheep given glucose infusions (equations 3 and 4 ). From an examination of values recorded by the authors with forty-four sheep on a wide variety of diets, including the present results, no significant relationship $(P>0.05)$ was found between plasma glucose concentration and the irreversible loss of $\left[{ }^{14} \mathrm{C}\right]$ glucose from plasma $\left(Y_{l^{\prime}}\right)(r=0.159, n=66)$ or $Y_{P} / W^{0.75}(r=0.107, n=66)$ wheer $W$ is the live weight of the animal. It is possible that if individual animals were examined a relationship may exist, and this would explain the relationship when fed and starved sheep are grouped, since the same animals are generally used as is evident 
in the relationship found by Bergman (r964). That is, individual sheep may control thcir plasma glucose concentration within narrow limits.

The disposal of infused glucose in ruminants has not been fully elucidated. The liver (and possibly the kidney) only partly 'adapt' to a glucose infusion in our study since the rate of suppression of plasma glucose synthesis was apparently less than the infused rate of glucose. Similar observations were recorded with dogs given glucose intravenously (Steele, Bishop, Dunn, Altszuler, Rathgeb \& de Bodo, I965; Hetenyi \& Wrenshall, I968). In ruminants, the conversion of glucose into fatty acids is also restricted by the virtual absence or negligible activity of ATP citrate lyase and malate (NADP) dehydrogenase of the citrate-cleavage pathway in adipose and liver tissue (Hanson \& Ballard, I967). Further, the activities of these enzymes do not appear to be markedly altered when diets of high grain content are fed (Young, Thorp \& De Lumen, 1969).

The studies of Annison \& White (I96I) and Bartley \& Black (I966) indicate that much of the exogenous glucose administered to ruminants is promptly oxidized. Since the irreversible loss of blood bicarbonate was not altered in the present studies, and hence energy expenditure probably remained constant during infusions of exogenous glucose, any increase in glucose oxidation must have displaced the oxidation of other substrates. The significantly greater estimates of the irreversible loss of blood bicarbonate in sheep maintained on the lucerne diet than in sheep maintained on the wheat diet (see Table $\mathrm{I}$ ) agree with the findings of Corbett, Farrell, Leng, McClymont \& Young (I97I) that the irreversible loss of blood bicarbonate provides a sensitive index of energy expenditure in sheep. Acetate is a major source of energy in ruminants (Annison, Brown, Leng, Lindsay \& West, 1967), and it is possible that an increased rate of oxidation of glucose spared acetate for lipogenesis in extrahepatic tissue (Škarda \& Bartoš, I969). Alternatively, the endogenous production of acetate may have been suppressed by the glucose infusions (Annison \& Lindsay, r96r). Free fatty acid metabolism is low in the fed sheep (West \& Annison, r.964) but glucose infusions could also have decreased the mobilization or oxidation of these substrates (Annison, I960).

In the present study, alterations in the irreversible loss of endogenous glucose with glucose infusions probably reflected changes in the rate of gluconeogenesis, since it is unlikely that the liver of ruminants has a great potential to store large amounts of glycogen (see Ballard, Hanson \& Kronfeld, r969), particularly when superimposed on levels of $30-5 \circ \mathrm{g} / \mathrm{kg}$ liver present in the fed sheep (Ford, I962). Bartley, Freedland \& Black (I966) reported that liver glycogen increased slightly, from about $\mathrm{i} 7$ to $26 \mathrm{~g} / \mathrm{kg}$ liver in cows given an intraduodenal infusion of I $\mathrm{g}$ glucose/min for $4 \mathrm{~h}$. However, these cows were probably not fed on the experimental day and the glycogen synthesized may have replenished that which was mobilized.

Krebs ( 1964 ) has proposed that the rate of gluconeogenesis (and glycolysis) can be controlled at certain 'pace-maker' reactions. One of these enzymes appears responsive, for in cow liver the activity of glucose-6-phosphatase is halved $4 \mathrm{~h}$ after the start of an intraduodenal infusion of glucose (Bartley et al. I966). Filsell, Jarrett, Taylor and Keech (I969) have shown that the concentration of another of these 
enzymes, pyruvate carboxylase, in the liver of sheep was very responsive to changes in hormonal and dietary perturbations. If pyruvate carboxylase activity was suppressed when glucose was infused this may have been effective in raising the availability of propionate relative to other substrates for glucose synthesis (see Table 3 ), concomitant with a reduction in the synthesis of glucose carbon from bicarbonate (see Table 2).

The liver cell is considered to be freely permeable to glucose (Cahill, Ashmore, Renold \& Hastings, 1959), so the concentrations of glucose in plasma and hepatic cells were probably similar. However, it is unlikely in the present study that increased plasma glucose concentrations per se suppressed glucose release through alterations in metabolite levels in the hepatic cell, since sheep liver apparently has a poor ability to utilize glucose, probably because of the absence of glucokinase (Ballard \& Oliver, I964; Ballard, 1965). Further, Ruderman \& Herrera (1968) could show only a small suppression of gluconeogenesis from alanine by $17 \mathrm{~mm}$ glucose in the isolated perfused rat liver, and Exton \& Park (1967) found no inhibition of gluconeogenesis from lactate by 19 mmol glucose with similar preparations of rat liver.

In the dog, suppression of endogenous glucose production by infused glucose is thought to be primarily the result of an increased secretion of insulin (see Steele, I966; Ishiwata, Hetenyi \& Vranic, 1969). Insulin has been shown to suppress glucose synthesis from pyruvate or lactate in perfused rat livers and in intact rats (sce Exton, Mallette, Jefferson, Wong, Friedmann, Miller \& Park, 1970; Friedmann, Goodman $\&$ Weinhouse, 1970 ) possibly by suppressing pyruvate carboxylase activity (Williamson, 1967; Scrutton \& Utter, 1968). It is possible that the effect of exogenous glucose on endogenous glucose production in sheep might also be largely mediated through an increased secretion of insulin, in response to raised concentrations of plasma glucose or increased flux rates of glucose through the plasma (see Boda, I964; Manns $\&$ Boda, I967; Horino, Machlin, Hertelendy \& Kipnis, I968), since intraportal infusions of insulin rapidly inhibit glucose release in sheep (West \& Passey, 1967).

Glucose-mediated effects or insulin, or both, may have also diminished the availability of glycerol or gluconeogenic amino acids for glucose synthesis. Bergman (1968) reported that the administration of glucose or insulin to ketotic sheep decreased the production rate of plasma glycerol, probably largely through inhibition of lipolysis since glycerol cannot be re-utilized for triglyceride synthesis in adipose tissue (Vaughan, 196r; Khachadurian, Kamelian \& Adrouni, 1967). The decreased plasma urea concentration indicates a decreased amino acid catabolism during infusions of glucose and is in accord with the report of Potter, Purser \& Cline (Ig68) that intra-arterial infusions of glucose in sheep, 6 and $24 \mathrm{~h}$ after feeding depressed plasma amino acid concentrations.

These possible extrahepatic effects of exogenous glucose are probably more effective in suppressing gluconeogenesis in the starved animal which relies in part, or wholly, on the mobilization of endogenous precursors for glucose synthesis. This may, in part, account for the almost complete suppression of glucose synthesis in sheep $24 \mathrm{~h}$ after feeding (Annison \& White, 196r; West \& Passey, 1967) but given infusions of glucose similar to those used in the present study, which were shown to only partly suppress endogenous glucose production (about $40 \%$ ) in the fed sheep. The linear 
relationship between the suppression of endogenous glucose production and glucose infused indicates, however, that further suppression of glucose synthesis in fed sheep may have been obtained with glucose infusions in excess of those used in the present study.

We gratefully acknowledge financial support from the Australian Wool Research Committee.

\section{REFERENCES}

Annison, E. F. (1960). Aust. F. agric. Sci. II, $5^{8}$.

Annison, E. F., Brown, R. E., Leng, R. A., Lindsay, D. B. \& West, C. E. (1967). Biochem. F. 104, 135. Annison, E. F. \& Lindsay, D. B. (I96x). Biockem. $7.78,777$.

Annison, E. F., Lindsay, D. B. \& White, R. R. (1963). Biochem. F. 88, 243.

Annison, E. F. \& White, R. R. (196r). Biochem. F. 80, 162.

Armstrong, D. G. \& Beever, D. E. (I969). Proc. Nutr. Soc. 28, IzI.

Baile, C. A., Mayer, J., Mahoney, A. W. \& McLaughlin, C. (1969). F. Dairy Sci. 52, ror.

Ballard, F. J. (1965). Comp. Biochem. Physiol. r4, 437.

Ballard, F. J., Hanson, R. W. \& Kronfeld, D. S. (1969). Fedn Proc. Fedn Am. Socs exp. Biol. 28,2 , 8.

Ballard, F. J. \& Oliver, I. T. (1964). Biochem. F. 92, I3 I.

Barker, J. N. \& Britton, H. G. (1957). F. Physiol., Lond. 138, 3 P.

Bartley, J. C. \& Black, A. L. (1966). F. Nutr. 89, 3 I7.

Bartley, J. C., Freedland, R. A. \& Black, A. L. (I966). Am. F. vet. Res. 27, 1243.

Beever, D. E., Coehlo da Silva, J. F. \& Armstrong, D. G. (r97o). Proc. Nutr. Soc. 29, 43 A.

Bergman, E. N. (1964). Nature, Lond. 202, 1333 .

Bergman, E. N. (1968). Am. J. Physiol. 215, 865.

Bittar, E. E. (1964). Cell $p H$. Washington: Butterworths.

Black, A. L., Egan, A. R., Anand, R. S. \& Chapman, T. E. (1968). In Isotope Studies on the Nitrogen Chain p. 247 . Vienna: I.A.E.A.

Boda, J. M. (1964). Am. F. Physiol. 206, 419.

Cahill, G. F. Jr, Ashmore, J., Renold, A. E. \& Hastings, A. B. (1959). Am. ₹. Med. 26, 264.

Clare, N. T. \& Stevenson, A. E. (1964). N.Z. Jl agric. Res. 7, 198.

Corbett, J. L., Farrell, D. J., Leng, R. A., McClymont, G. L. \& Young, B. A. (197x). Br. F. Nutr. 26, 277.

Exton, J. H. \& Park, C. R. (1967). F. biol. Chem. 242, 2622.

Exton, J. H., Mallette, L. E., Jefferson, L. S., Wong, E. H. A., Friedmann, N., Miller, T. B. \& Park, C. R. (1970). Recent Prog. Horm. Res. 26, $41 \mathrm{I}$.

Felts, J. M. \& Mayes, P. A. (1967). Biochem. F. 105, 735.

Filsell, O. H., Jarrett, I. G., Taylor, P. H. \& Keech, D. B. (1969). Biochim. biophys. Acta 184, 54.

Ford, E. J. H. (1962). F. agric. Sci., Camb. 59,67.

Ford, E. J. H. (1965). F. agric. Sci., Camb. 65, 41.

Friedmann, B., Goodman, E. H. \& Weinhouse, S. (1970). Endocrinology 86, 1264.

Gurpide, E., Mann, J. \& Lieberman, S. (1963). J. clin. Endocr. Metab. 23, I 155.

Hanson, R. W. \& Ballard, F. J. (r967). Biochem. F. ro5, 529.

Hetenyi, G. Jr \& Wrenshall, G. A. (I968). Can. F. Physiol, Pharmac. 46, 39 I.

Horino, M., Machlin, L. J., Hertelendy, F. \& Kipnis, D. M. (I968). Endocrinology 83, I 8.

Huggett, A. St G. \& Nixon, D. A. (1957). Biochem. $\%$. 66, I2 P.

Ishiwata, K., Hetenyi, G. Jr \& Vranic, M. (1969). Diabetes 18, 820.

Jones, G. B. (1965). Analyt. Biochem. 12, 249.

Judson, G. J., Anderson, E., Luick, J. R. \& Leng, R. A. (I968). Br. F. Nutr. 22, 69.

Judson, G. J. \& Leng, R. A. (1968). Proc. Aust. Soc. Anim. Prod. 7, 354.

Judson, G. J. \& Leng, R. A. (1970). Proc. Aust. biochem. Soc. 3, 41.

Kerr, R. W. (editor) (1950). Chemistry and Industry of Starch p. 99. New York: Academic Press.

Khachadurian, A. K., Kamelian, M. \& Adrouni, B. (r967). Am. F. Physiol. 213, ${ }_{3} 85$.

Krebs, H. (1964). Proc. R. Soc. B I59, 545.

Leng, R. A. (1970). Adv. vet. Sci. 14, 209.

Leng, R. A. \& Leonard, G. J. (I965). Br. F. Nutr. I9, 469.

Leng, R. A., Steel, J. W. \& Luick, J. R. (1967). Biochem. f. ro3, 785.

MacRae, J. C. \& Armstrong, D. G. (I969). Br. F. Nutr. 23, 377.

Manns, J. G. \& Boda, J. M. (r967). Am. F. Physiol. 212, 747. 
Ørskov, E. R. (1969). Revta cub. Cienc. agric. 3, I.

Orskov, E. R., Fraser, C. \& Kay, R. N. B. (r969). Br. F. Nutr. 23, 217.

Potter, E. L., Purser, D. B. \& Cline, J. H. (I 968). F. Nutr. 95, 655.

Reid, R. L. (1958). Aust. Y. agric. Res. 9, 788.

Roughton, F. J. W. (1935). Physiol, Rev. 15, 241.

Ruderman, N. B. \& Herrera, M. G. (I968). Am. F. Physiol. 2x4, 1436.

Scrutton, M. C. \& Utter, M. F. (1968). A. Rev. Biochem. 37, 249.

Škarda, J. \& Bartoš, S. (1969). Ұ. Endocr. 44, i I 5.

Steel, J. W. \& Leng, R. A. (1968). Proc. Aust. Soc. Anim. Prod. 7, 342.

Steele, R. (1966). Ergebn. Physiol. 57, 91.

Steele, R., Bishop, J. S., Dunn, A., Altszuler, N., Rathgeb, I. \& de Bodo, R. C. (1965). Am. $\mathcal{F}$. Physiol. 208, 301

Szabo, A. J., Maier, J. J., Szabo, O. \& Camerini-Davalos, R. A. (1969). Diabetes x8, 232.

Tait, J. F. (1963). F. clin. Endocr. Metab. 23, 1285.

Tucker, R. E., Mitchell, G. E. Jr \& Little, C. O. (1968). F. Anim. Sci. 27, 824.

Vaughan, M. (1961). F. Lipid Res. 2, 293.

West, C. E. \& Annison, E. F. (1964). Biochem. F. 92, 573.

West, C. F. \& Passey, R. F. (r 967). Binchem. $\mathcal{F}$. 102, 58 .

Williamson, J. R. (I967). Adv. Enzyme Regul. 5, 229.

Young, J. W., Thorp, S. L. \& De Lumen, H. Z. (1969). Biochem. \%. Ir4, 83. 